\title{
An investigation of Toxoplasmosis in Free Range chickens, Industrial chickens and Duck in mid Euphrates area of \\ Iraq
}

\author{
M. J. A. Alkhaled \\ Coll.of Vet. Med/Univ. of \\ Al-Qadisiyia
}

\author{
A. Y. Yakoob \\ Coll.of Vet.Med/Univ. of \\ Baghdad
}

\author{
A. H. U. AL-hamadani \\ Coll.of Med/Univ. of Al- \\ Qadisiyia
}

The current study determined the prevalence of Toxoplasmosis among the free Range Chicken, Industrial Chicken and Duck by using LAT and ELISA .A total of 200 FR Chicken purchased (70 Al-qadisyia province, 65Al-najaf province, and 65 Babylon province), 200 Industrial Chicken purchased from ten Industrial farms in geographical different region of AlDiwania city and 50 Duck purchased(rural area and bird sale places of Al-Diwania city) were involved in this study, one hundred thirty four (67\%) of FR Chicken, Sixty two (31\%) of Industrial chicken and twenty eight (56\%) of Duck, were diagnosed primarily as Toxoplasmosis by LAT.Out of 90 ( 45 FR Chicken and 45 Industrial Chicken ) of LAT positive cases, only $36 \%$ were positive by ELISA which considered as confirmed Toxoplasmosis cases .Results revealed that $51.11 \%$ and $28.88 \%$ of FR chicken and Industrial chicken positive by ELISA respectively.The percentage of $T$. gondii antibodies in FR chickenby LAT were $71.42 \%, 69.23 \%$ and $55.38 \%$ in Al-Qadissiya, Babylon and in Al-najaf provinces respectively whereas the percentage by ELISA were $66.66 \%, 46.66 \%$ and $33.33 \%$ in Al-Qadisiya, Babylon and in Al-najaf respectively.Although the difference observed in the percentage of $T$. gondii antibodies among different provinces, there was no significant differences $\mathrm{P}>0.05$ detected by LAT whereas in the ELISA there was significant differences $\mathrm{P}>0.05$. The highest titer in LAT were $1 / 128(34.32 \%)$ in FR chicken, $1 / 8(29.3 \%)$ in the Industrial chicken and 1/32(35.7 \%) in the Duck, The lowest titer were 1/2 (5.22\%) in FR chicken , $1 / 128(0 \%)$ in the Industrial chicken and 1/4(0\%) in the Duck.

\section{Introduction}

Toxoplasma gondii is an obligate intracellular protozoan that infects humans and a wide range of mammalian and bird (1).Its high infection rates and its benign co-existence with the host, T.gondii is regarded as one of the most successful parasites on earth . is a global parasites with no known geographical boundaries (2). Serological surveys done in various parts of the world show that in some countries more than a third of the human population have antibodies against T.gondii .This high prevalence of infection in human proves the importance of toxoplasmosis as azoonotic disease $(3,4)$.T.gondii infection in freerange chickens (FR) is considered important as FR chickens are one of the best indicators for soil contamination with T.gondii oocysts because they feed from the ground, and tissues of infected chickens are considered a good source of infection for cats. Additionally, ingestion of infected chicken meat can be a source of infection for T.gondii infection in humans and other animals. Rarely, toxoplasmosis can cause clinical disease in chickens (5).Soil contaminated with oocysts can be taken up by pastoral animals, such as sheep and goats, during grazing. Poultry having outdoor access will also take up considerable amounts of soil and can thus become infected with Toxoplasma. Therefore, free-ranging chickens are now used as sentinel animals to isolate and characterise Toxoplasma strains throughout the world (6).

The aim of the study:

Investigate the utility of enzyme linked immunosorbent assay (ELISA) for detection infections with $T$. gondii in chickens and whether it can be used as a confirmatory assay to determine the infections with positive Latex Agglutination Test(LAT) results. 


\section{Materials and Methods}

- Samples Collection:

- Free range chicken samples

A total 200 chicken samples were cluster screening randomly purchased from chickens of rural geographical properties of AL-Qadisiya, AL-Najaf and Babylon provinces in 2010. Since female gender ranged 2-5 years old was destined for meat and egg production, they were dominated more than $90 \%$ in this study.

- Industrial chicken samples:

Totally 200 chicken samples were purchased from ten industrial farms. in geographically different regions of ALQadisiya province .

\section{- Duck}

A total of 50 Duck purchased from rural area and AL- Diwaniyah bird sale places in geographically different regions of of AL- Qadisiya province .

\section{- Blood samples}

Five milliliter $(\mathrm{ml})$ of blood was drawn from each bird heart by disposable syringe. blood were collected in sterile plain tubes and left 30 minutes at room temperature to clot, then centrifuged at
$3000 \mathrm{rpm}$ for 5 minutes for serum collection which was aspirated by using micropipette and dispensed into another sterile tubes, each serum was divided into 2 tubes, and kept in deep freeze at $-20^{\circ} \mathrm{C}$.

- The Diagnostic Methods:

$\quad$ Latex Agglutination
[PLASMATEC
Kingdom]

Two hundred sample of free Ranging chicken, Two hundred sample of industrial chicken and fifty Ducks sera were involved in this test.

- Enzyme Linked Immunosorbant Assay (ELISA).

This is kit product of the European Veterinary Laboratories (EVL), Holland origin, and was performed according to the manufacturer's instructions, this kit used the whole parasite protein of cell membrane as antigen and determined the antibodies in the sera of animals, and stored at $\pm 4^{\circ} \mathrm{C}$ until used. figure ( 1 ). Ninety sera (45 free Ranging chicken, 45 industrial chicken ) sero-positive sera by LAT test.

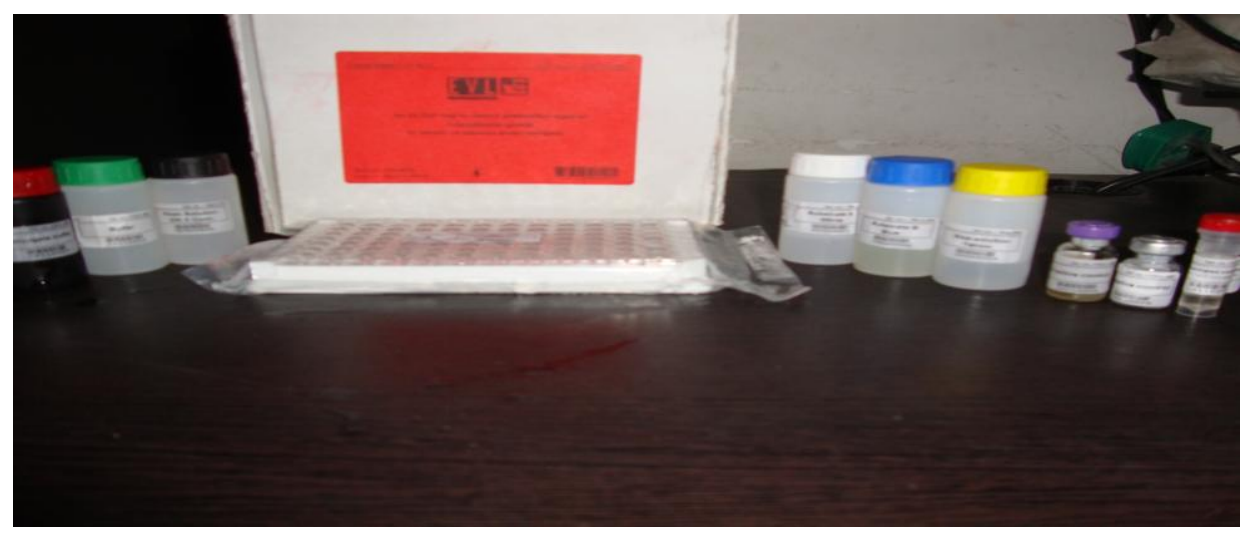

- Statistical Analysis

Data were analyzed by digital interactive Chi-square test program, $\mathrm{P}$
Fig. (1)Toxoplasma (ELISA kit)

value $\leq 0.05$ was considered statistically significant $(7)$

\section{Result and Discussion}

Sero -Incidence:

- Latex Agglutination Test (LAT):

- Incidence of Toxoplasmosis Cases

According to breed of chicken.

(FR chicken and Industrial chicken)
According to LAT, the high rate of Toxoplasmosis cases $(67 \%)$ in FR chicken and the lowest rate of Toxoplasmosis cases among industrial chicken (31\%) Table(1) 
Table(1 ) No. of sero-positive cases of toxoplasmosis in FR chicken, Industrial chicken and Duck by LAT.

\begin{tabular}{|c|c|c|c|}
\hline Type of bird & Total & $\begin{array}{c}\text { Positive } \\
\text { No. }\end{array}$ & $\begin{array}{c}\text { Percentage } \\
\%\end{array}$ \\
\hline FR chicken & 200 & 134 & 67 \\
\hline Industrial chicken & 200 & 62 & 31 \\
\hline Duck & 50 & 28 & 56 \\
\hline
\end{tabular}

The LAT was used for the general detection of toxoplasmosis because it is relatively a simple, cheap and provided an efficacious method for routine serological screening for antibodies to $T$. gondii (8).Then the LAT results were further tested with ELISA test to increase the accuracy of diagnosis because of the high specificity and sensitivity of this test (9).This present study showed the high percentage of antibody titer against $T$. gondii positive by LAT among FR chicken. This result indicate high distribution of toxoplasmosis among chicken in the studied area.Our finding demonstrated that anti $T$. gondii antibodies were high in FR chickens in the studied area .it seems that become infected mostly during feeding on the ground contaminated with oocysts. (10). The prevalence rate of anti Toxoplasma antibody in FR chicken $(67 \%)$ in present study was higher than that of ELmassry etal survey(47.2\%) from Giza province in Egypt (11). The role of these FR chicken as intermediate host and disseminator of oocysts (12). The prevalence of infection in industrial chickens was $31 \%$ that is close to that of Ghorbani etal survey $30.3 \%$ which was reported in Iran (13). The $31 \%$ prevalence of $T$. gondii antibodies in chickens was used for food in Iraq was higher than 9.5\% prevalence in chicken reported from India (14).Since industrial chicken that reared in saloons rose for meat production in short duration and less exposed to cat feces, these chicken had the lowest prevalence compared to FR chicken .T. gondii antibodies were reported to be present in $53.3 \%$ of chickens in Egypt by sabinfeldman dye test ,indirect hemagglutination assay (IHA), or the complement fixation test $(15,16)$. However, IHA and the dye test were found to be insensitive for detecting $T$. gondii antibodies in experimentally infected chicken The prevalence of $T$. gondii in chickens, as determined by the modified agglutination test (MAT)(17) varies within countries, ranging from $10 \%$ to $47 \%$ $(11,14,18,19,20)$. The many factors such as management and hygienic standards in breeding, density of cat and environmental condition are effect on the acquisition of $T$. gondii oocyst by animal.

\section{Ducks}

Results revealed that the LAT detected 28seropositive cases from total selected 50 case in percentage $56 \%$.The prevalence of infection in Duck 56\% was nearly similar to those recorded in Duck of Egypt $50 \%$ (11).The $56 \%$ seroprevalence of $T$. gondii in Duck in the present study is markedly higher than the $1.7 \%$ prevalence reported by (21).In the table ( 2 ) the result recorded the highest percentage of the presence of $T$. gondii antibodies detected by LAT was in AL-Qadisiyia 71.42\%, whereas the lowest percentage was in the AL-Najaf $55.38 \%$, results showed no significant difference among these provinces. 
Table (2) sero-positive cases and T.gondii antibodies percentage in different provinces by LAT in FR chicken.

\begin{tabular}{|c|c|c|c|}
\hline Province & Total & Serpositive No. & Percentage \% \\
\hline AL-Qadisiyia & 70 & 50 & 71.42 \\
\hline AL-Najaf & 65 & 36 & 55.38 \\
\hline Babylon & 65 & 45 & 69.23 \\
\hline Total & 200 & 134 & 67 \\
\hline
\end{tabular}

$\mathrm{X}^{2}=6.5$

$\mathrm{P}<0.05$

Result showed that no significant differences was present among different provinces by LAT test, which may be due to all these provinces included in this study located in mid Euphrates area of Iraq which was similar in the nature of climatic condition.

\section{Antibodies titration}

The highest titers were $1 / 128$ $(34.32 \%)$ in FR chicken , 1/8 (29.3\%) in the Industrial chicken and 1/32(35.7\% \%) in the Duck respectively, as illustrated in Table (3). The percentage of antibody against $T$. gondii in FR chicken at a titer $1 / 128$ was $34.32 \%$ this is lower than that reported in FR chicken of Iran by( 22). The present study result is not compatible with the result recorded by Lindsay etal. Who reported $45.45 \%$ that was at atiter $1 / 160$ in broiler chicken (23).

Table (3)Percentages of antibody titers in (FR chicken, Industrial chicken and Duck) by LAT.

\begin{tabular}{|r|c|c|c|c|c|c|c|c|}
\hline Titer & $1 / 2$ & $1 / 4$ & $1 / 8$ & $1 / 16$ & $1 / 32$ & $1 / 64$ & $1 / 128$ & $1 / 256$ \\
\hline $\begin{array}{c}\text { Fvian } \\
\text { Chicken }\end{array}$ & $5.22 \%$ & $8.2 \%$ & $7.46 \%$ & $9.7 \%$ & $10.44 \%$ & $12.68 \%$ & $34.32 \%$ & $11.94 \%$ \\
\hline $\begin{array}{l}\text { Industrial } \\
\text { Chicken }\end{array}$ & $6.45 \%$ & $9.67 \%$ & $29.3 \%$ & $16.12 \%$ & $12.9 \%$ & $6.45 \%$ & $0 \%$ & $4.83 \%$ \\
\hline Duck & $7.14 \%$ & $0 \%$ & $10.71 \%$ & $3.57 \%$ & $35.7 \%$ & $13.71 \%$ & $17.85 \%$ & $14.28 \%$ \\
\hline
\end{tabular}

L.S.D $=31.3$

$\mathrm{P}<0.05$

The high prevalent of antibodies titer in FR Chicken at titer 1/128 and in Duck at titer $1 / 32$ in this study may be attributed to the nature of infection in which most of FR Chicken at age (2-5 years) which may be previously suffered from chronic infection while the high prevalent of antibodies titer infected Industrial Chicken at a titer $1 / 8$ may be due to the modern infection in those Industrial chicken which less stimulated to Immunity.

Table (4) No. of sero-positive cases of toxoplasmosis in different chicken by ELISA.

Table (4) No. of sero-positive cases of toxoplasmosis in different chicken by ELISA.
\begin{tabular}{|c|c|c|c|}
\hline Type of Chicken & No. of examined & $\begin{array}{c}\text { Positive } \\
\text { No. }\end{array}$ & $\begin{array}{c}\text { Percentage } \\
\%\end{array}$ \\
\hline FR Chicken & 45 & 23 & 51.11 \\
\hline Industrial Chicken & 45 & 13 & 28.88 \\
\hline total & 90 & 36 & 40 \\
\hline
\end{tabular}

$\mathrm{X}^{2}=6$

$\mathrm{P}<0.05$

\section{ELISA}

\section{-Incidence of Toxoplasmosis Cases} According to breed of chicken.

out off (90) sera samples which were seropositive in LAT tested a total of 36 were positive. The highest percentage of $T$. gondii antibodies was in FR chicken $51.11 \%$ but the lowest percentage was in the industrial chicken $28.88 \%$ as shown in table (4).

\footnotetext{
P<0.05
} 
ELISA was used for confirming the results of latex agglutination test (LAT), because of the ELISA is of a great sensitivity, objective, quantitative and may be automatically adopted, although it needs a refinement in the procedures.(24).A significant difference $\mathrm{P} \leq 0.05$ was detected in the percentage of $T$. gondii antibodies among FR Chicken and Industrial chicken by ELISA, Bird and rodents are two of the most important intermediate hosts. they become infected easily through ingestion of oocysts (25).Dubey et al. (1993) studied the serologic response of four-week-old chickens to $T$. gondii following oral oocyst inoculation. In his study, both the modified agglutination test and ELISA test detected antibodies within two weeks of inoculation and to the termination of the experiment at 68 days post-inoculation. Other workers have used an ELISA test to demonstrate that chickens and pigeons inoculated with T. gondii oocysts seroconvert within 2 and 3 weeks, respectively(26).Soil is the most important source of infection for intermediate hosts and, owing to the feeding behavior of terrestrial species, e. g. chickens and partridges, the prevalence of $T$. gondii in these hosts is a good indicator of environmental contamination with parasite oocysts (14). which indicates that FR Chicken are more likely to get infection than those which are Industrial chicken.The prevalence rate of toxoplasmosis in FR chicken by ELISA was nearly similar to those of Chinese infected FR Chicken $(34.7 \%)$ while The prevalence rate of toxoplasmosis in Industrial chicken by ELISA was much higher than that reported in Chinese infected caged chicken (2.8\%) (27). The lower prevalence rate in the Industrial chicken in the present study could be due to various reasons. It possible that the samples that were analyzed here in originated from younger Chicken. this theory is supported by the fact that the highest titer obtained in this study was only $1 / 8$, which was much less than that obtained elsewhere (28). Thus it is entirely possible that a younger age of industrial chicken were sampled leading to lower prevalence.A significant difference $\mathrm{P} \leq 0.05$ was detected among different province of in the percentage of $T$. gondii antibodies in FR chicken by ELISA, and the highest percentage of T.gondii antibodies was seen in AL-Qadisiyia 66.66\%, while the lowest was detected in AL-Najaf 40\%, as shown in table (5) below.The significant differences that was observed in the percentage of $T$. gondii antibodies among different provinces, which could be attributed to increasing opportunities of exposure to several sources of Toxoplasmosis infection and this were evident that ELISA were more accurate , and could be detected different parts of antibodies .

Table (5) No. of sero-positive cases of toxoplasmosis in different chicken and provinces by ELISA.

\begin{tabular}{|c|l|l|c|c|}
\hline $\begin{array}{c}\text { Type of } \\
\text { chicken }\end{array}$ & province & total & $\begin{array}{c}\text { Positive } \\
\text { No. }\end{array}$ & $\begin{array}{c}\text { Percentage } \\
\%\end{array}$ \\
\hline FR & AL-Qadisiyia & 15 & 10 & 66.66 \\
\hline FR & Babylon & 15 & 7 & 46.66 \\
\hline FR & AL-Najaf & 15 & 6 & 40 \\
\hline industrial & AL-Qadisiyia & 45 & 13 & 28.88 \\
\hline \multicolumn{2}{|r|}{ total } & 90 & 36 & 40 \\
\hline
\end{tabular}

$\mathrm{X}^{2}=5.9$

$\mathrm{P}<0.05$ 


\section{References}

1. Smith, J.E.and Reduck, N.R. (2000). Toxoplasma gondii strain variation and pathogenicity. In: Cary, J.W., Linz, J.E., Bhatnagar, B. (Eds), Microbial foodborne diseases: mechanisms of pathogenesis and toxin synthesis. Technomic Publishing, Lan- caster, PA,: 405-431.

2. Carruthers, V. B. (2002). Host cell invasion by opportunistic Toxoplasma gondii .Acta Tropica 81 (2) :111-122.

3. Tenter, A. M.; Heckeroth, A. R. andWeiss, L. M.(2000). Toxoplasma gondii from animals to human. Inter. J. parasitol., 30:1247-1258.

4. A,aiz, N.N., (2010). Genotyping Analysis to determine the main lineages types of Toxoplama gondii with study of of antibodies production by Toxoplasmosis patients. Ph.D thesis. college of science, Kufa university.

5. Dubey, J.P. (2010). Toxoplasma gondii infections in chickens (Gallus domesticus): Prevalence, clinical disease, diagnosis, and public health significance. Journal of Zoonosis and Public Health in press, 57:60-73.

6. Lehmann, T.; Marcet, P.L.; Graham, D.H.; Dahl, E.R.and Dubey, J.P. (2006). Globalization and the population structure of Toxoplasma gondii. Proc. Natl. Acad. Sci. 103, 11423-11428.

7. Preacher, K.J.(2001) Digital interactive Chi-square test program.Uni. Kansas.

8. Hasson, K. F. (2004). Seroepidemiological study of toxoplasmosis among pregnant women with gynecological and obstetrical problems in Najaf city. M. Sc. Thesis, college of medicine, Kufa university.

9. Shaapan,R.M.; El-Nawawi, F.A.; and Tawfik, M.A.(2008). Sensetivity and specificity of various serological tests for the derection of Toxoplasma gondii infection in naturally infected sheep.Vet.Parasitol.,153:359-362.

10. Ruiz, A.and Frenkel, J.K., (1980). Intermediate and transport hosts of Toxoplasma gondii in Costa Rica. Am. J. Trop. Med. Hyg. 29, 1161-1166.

11. El-Massey, A.; Mahdy, O. A.; ElGhaysh, A.and Dubey, J.P., (2000). Prevalence of Toxoplasma gondii antibodies in sera of turkeys, chickens, and ducks from Egypt. J. Parasitol. $86,627-628$.

12. Zumbado, S.G., Miranda, J.G., Bermidez, G.O. and Chinchilla, M., (2000). Elminacion de ooquistes de Toxoplasma gondii en politos despues de una infection experimental. clencias, 23,25-34.

13. Ghorbani M.; Gharavi M. J.and Kahnamoui A. (1990). Serological and parasitological investigations on Toxoplasma infection in domestic fowls in Iran. Iranian J Pub Health.; 19: 917.

14. Devada, K.; Anandan, R. and Dubey, J. P. (1998). Serologic prevalence of Toxoplasma gondii in chickens in Madras, India. J. Parasitol. 84, 621-622.

15. Rifaat, M. A.; Morsy, T. A. and Sadek, M. S. M. (1969). Toxoplasmosis in chickens and pigeons in U.A.R. (Preliminary report). J. Trop. Med. Hyg. 72, 193-194.

16. Hassanian, M. A.; Zayed, A. A.; Derbala, A. A. and Kutkat, M. A. (1997). Serological diagnosis of Toxoplasma gondii (Apicomplexa: Toxoplasminae) infection in laying hens. Egyptian Journal of Applied Science 12: 18.

17. Dubey, J. P.; Ruff, M. D. ; Camargo, M. E. ; Shen, S. K. ;Wilkins, G. L.; Kwok, O. C. H. and Thulliez, 
P. (1993). Serologic and parasitologic responses of domestic chickens after oral inoculation with Toxoplasma gondii oocysts. Am. J. Vet. Res. 54, 1668-1672.

18. Da Silva, D. S.; Bahia-Oliveira, L. M. G. ; Shen, S. K.; Kwok, O. C. H.; Lehmann, T. and Dubey, J. P. 2003: Prevalence of Toxoplasma gondii in chickens from an area in southern Brazil highly endemic to humans. J. Parasitol. 89, 394396.

19. Dubey, J. P.,(2003) . Toxoplasma gondii isolates from free ranging chickens from the united states. journal of parasitology, 89,10601062.

20. Dubey, J. P., Graham, D. H. Dahl, E. Hilali, M. El-Ghaysh, A. Sreekumar, C. Kwok, O. C. H. Shen, S. K. and Lehmann, T. (2003). Isolation and molecular characterization of Toxoplasma gondii from chickens and ducks from Egypt. Vet. Parasitol. 114, 89-95.

21. LITERA' K, I., AND HEJLi' $\mathrm{C}^{\sim}$ EK. K.(1993). Incidence of Toxoplasma gondii in populations of domestic birds in the Czech Republic. Avian Pathology 22: 275-281.

22. Asgari, Q.; Farzaneh, A.; Kalantari, M.; Akrami Mohajeri, F.; Moazeni, M.; Zarifi, M.; Esmaeilzadeh, B.and Motazedian, MH. (2006). Seroprevalence of free-Ranging chicken toxoplasmosis in sub-urban regions of Shiraz, Iran. Int J Poult Sci.; 5: 262-264.

23. Lindsay, D. S.; Smith, P.C.and Blagurn, B.C.,(1994). prevalence and Isolation of Toxoplasma gondii from wild turkey in Alabam. J Helmintholo Socity Washington.61:115-117

24. Gamble, H.R.; Dubey, J.P. \& Lambillotte, D.N. (2005). Comparison of commercial ELISA with the modified agglutination test (MAT) for detection of Toxoplasma infection in domestic pigs. Vet. Parasitol. 182(3-4):177-181.

25. Beaver,P.C., Jung, R.C. and Cupp, E.W.(1990).coccidia,

microsporidiay pneumocystis. In: parasitologia Clinica, $2^{\text {nd }}$, edn, (salvat Mexicana, Mexico),179184.

26. Biancifiori, F.; Rondini, C.; Grelloni, V. and Frescura, T. (1986).Avian toxoplasmosis: experimental infection of chicken and pigeon. Comp. Immunol. Microbiol. Infect. Dis. 9, 337-346.

27. Zhu, J.; Yin, J.; Xiao, Y.; Jiang, N.; Ankarlev, J.; Lindh, J. and Chen, Q. (2008). A seroepidemiological survey of Toxoplasma gondii infection in free-range and caged chickens in northeast china. Vet. Parasitol. 158, 360-363.

28. Dubey, J. P.; Graham, D. H. ; Blackston, C. R. ; Lehmann, T. ; Gennari, S. M. ; Ragozo, A. M. A. ; Nishi, S. M. ; Shen, S. K.; Kwok, O. C. H. ; Hill, D. E. and Thulliez, P.( 2002).Biological and genetic characterisation of Toxoplasma gondii isolates from chickens (Gallus domesticus) from $\mathrm{Sa}^{\sim}$ Paulo, Brazil: unexpected findings. Int. J. Parasitol. 32, 99-105. 


\title{
التحري عن داء المقوسات في الاجاج حر المعيشة والاجاج التجاري والبط في وسط العجاج جراق
}

\author{
عدنان حمد عبيد الحمداني

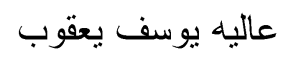 \\ منصور جدعان علي الخالدي

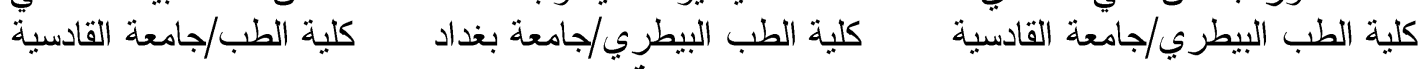

\section{الخلاصة اليطري}

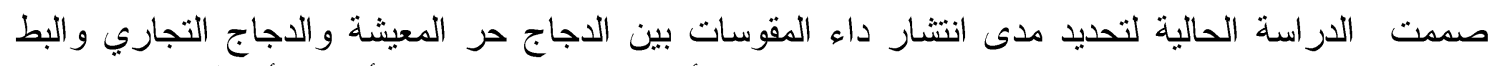

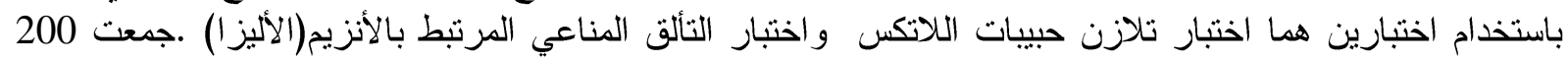

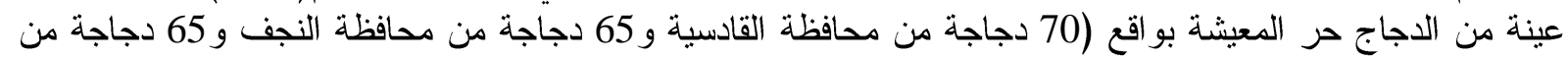

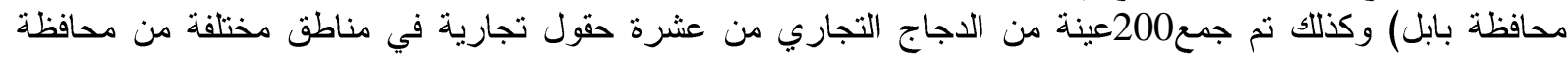

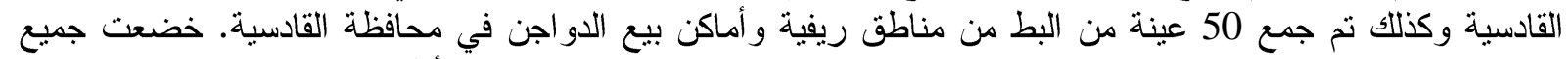

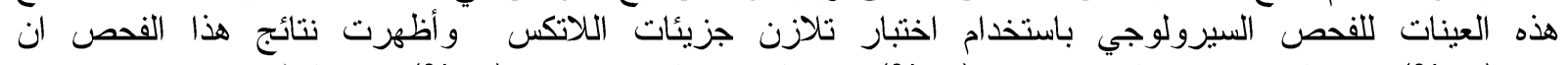
134(67\%) من الدجاج حر المعيشة و62(31\%) من الدجاج التجاري و28(56\%) من البط كانت مصابة بداء

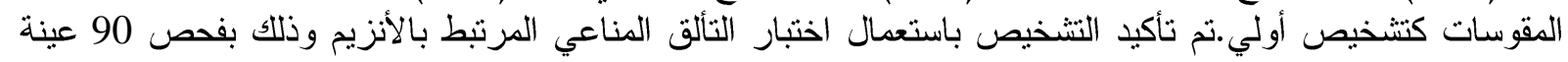

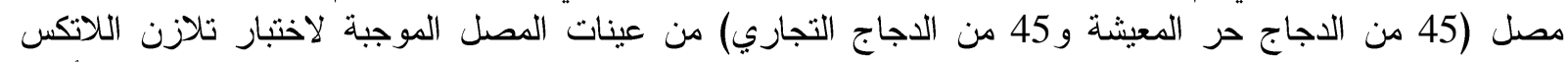

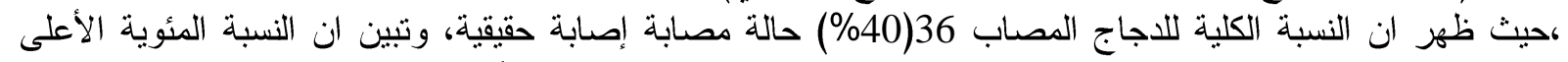

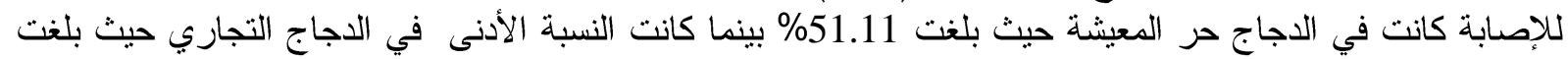

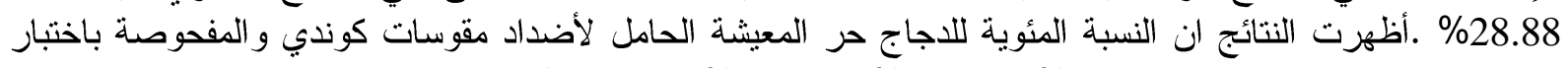
تلازن حبيبات اللاتكس كانت

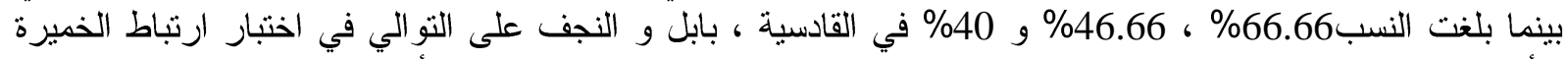

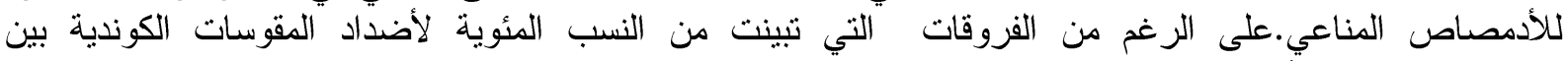

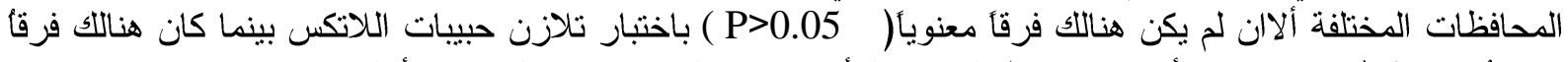

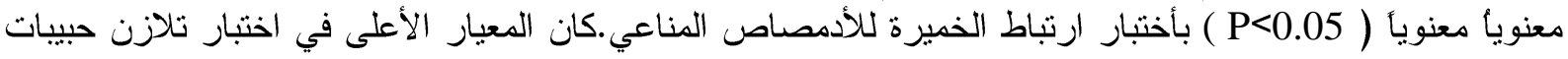

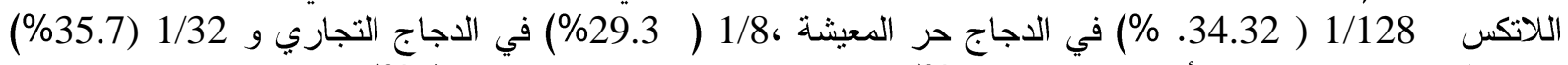
في البط بينما كان المعيار الأدنى 1/2 ( $1 / 28$ (5.22\%) في الدجاج حر المعيشة ، 1/128(0\%) في الدجاج التجاري و $1 / 4$ (\%) في البط بن 